\title{
Why is freshwater important to humanity
}

\author{
Nguyen Khanh Linh \\ Hoang Phuong Linh \\ Nguyen Thuy Linh \\ Truong Khanh Linh \\ Phung Thi Nhat Linh
}

\author{
Nguyen Duc Manh \\ Tran Thi Ngoc Mai \\ Nguyen Trong Minh \\ Le Hong Thao My \\ Đang Vinh Nam
}

\author{
Vietnam National University, Hanoi \\ Xuan Thuy, Cau Giay, Hanoi
}

Vietnam, January 22, 2022;

Preprint DOI: https://osf.io/c7tgr

In the modern world, parallel with the outstanding development of technology and economy is the gradual depletion of natural resources over time. And freshwater is one of the resources that plays an important role in human life but has not received much attention. According to some researched sources, there are reports that: the annual per capita water volume in North Africa and West Asia decreases by more than $30 \%$ and very rarely reaches $1,000 \mathrm{~m} 3$, although this is a milestone. represents the threshold of severe water scarcity.(Son, 2020) "In the US about 40\% of rivers in US cities are experiencing water pollution. Bangladesh is facing the risk of 1.2 million people having to use polluted water. Here, up to $85 \%$ of the water source is polluted." (Thoan, 2021) In Vietnam, every year, the number of people who die from lack of clean water is more than 9,000 people, and the number of people with cancer caused by using contaminated water is more than 200,000 people.(Eco248, 2021)

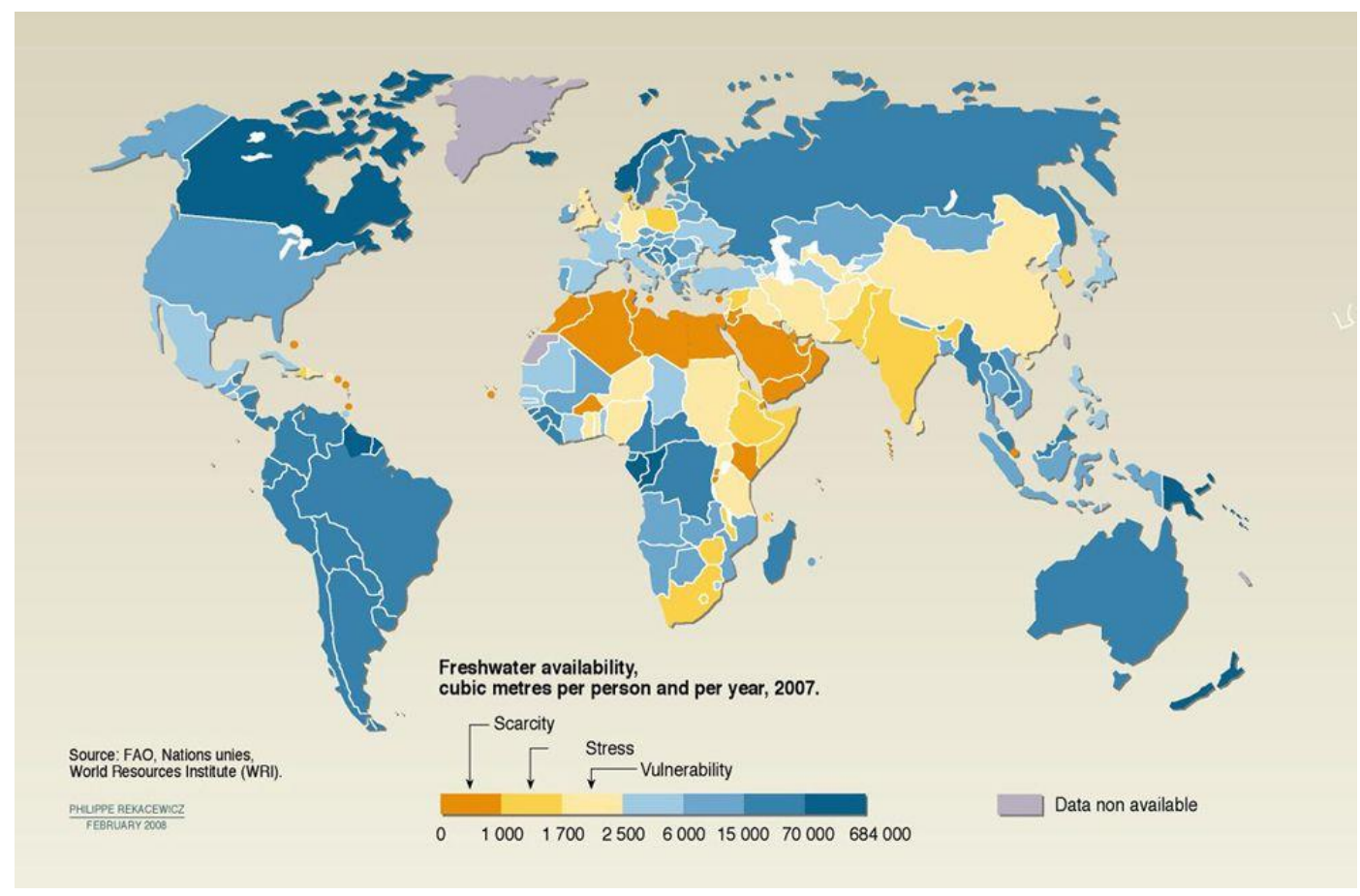

Figure 1. Map of the level of meeting the level of clean water needed for each person in countries around the world in 2007.(Rekacewicz, 2008) 
The causes of the global depletion of freshwater are many. The first reason is due to population growth. When the consumption of natural resources increases suddenly, nature will not have enough strength to recover resources quickly. Along with that, toxic substances from a large amount of domestic waste will contaminate freshwater sources. According to estimates by the United Nations, the world population in 2050 will reach 9 billion people (an increase of about 22.2\% compared to 2021), and in the following years the time of population growth of 1 billion people will be shortened. As a result, today 220 million people in cities in the developing world live without clean water and 1.1 billion people suffocate in polluted air.(Nước, 2021)

The second reason, although the level of waste treatment technology is increasingly being expanded and improved, compared to the amount of waste that people are discharging into the environment, there is still a huge disparity. Not every country is qualified to maintain a good waste treatment process to the required standards. The sense of thrifty consumption and poor environmental hygiene is also one of the causes leading to the depletion of freshwater resources in particular and natural resources in general. For example, right now in Vietnam, the waste treatment technology being applied is mainly quite rudimentary. Most of the waste is treated by burying or incinerating and these technologies are not really effective, even creating more pollution. Waste treatment in urban areas is a hot issue not only in Vietnam but also globally.(Chi, 2021)

The third reason is due to the development of agriculture, industry and health. Many countries use fertilizers and pesticides with many toxic chemicals to fertilize plants without realizing that these toxic substances will seep into the soil and contaminate groundwater. Regarding industrialization, although the development of industry is to meet human needs, it increases the amount of wastewater and chemical solutions leading to many places not being treated properly and discharged directly. our water source. Medical wastewater from hospitals and laboratories always carries pathogens, viruses or toxic chemicals, which, when not treated, will certainly bring diseases that threaten water sources from there. serious to human health. In China, the annual volume of industrial waste and wastewater discharged in cities and towns increased from 23.9 billion $\mathrm{m} 3$ in 1980 to 73.1 billion $\mathrm{m} 3$ in 2006.(Phụng, 2021)

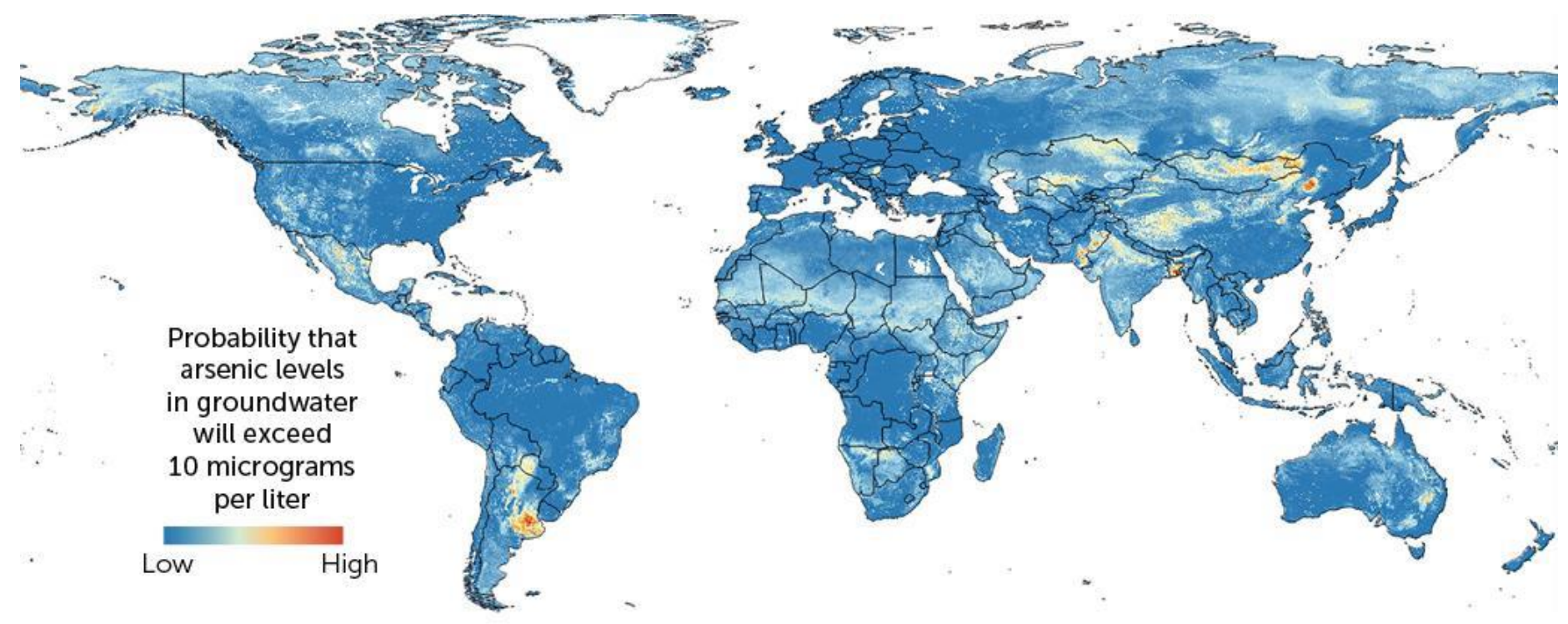

Figure 2. Map of places at risk of arsenic contamination in groundwater in the world 2020.(Joel Podgorski, 2020) 
At the millennium goals summit (MDGs) held in New York from September 20-22, 2010, the country was not given the rightful place in published documents or action plans.(Thiennhien.net, 2021) According to an employee of the Environmental Protection Fund EPF, China's policy of urban development and industrialization has made more than a quarter of the water sources here polluted to an alarming level and cannot be used for daily life. day; $35 \%$ of drinking water is not guaranteed to be clean water.(Nhóm thực hiện Trường Đại học Nông Lâm Thành phố Hồ Chí Minh, 2013) The contradiction between environmental policies is reflected in the attitude of people to consume resources. The depletion of clean water sources originates from indiscriminate consumption, the lack of self-discipline of people in the responsibility to protect the environment. This can lead to many conflicts over human rights by seriously affecting people's health, quality of life, social security, etc. Massive loss of livelihoods, migration and famine are just a few examples. These can increase disputes between rival ethnic groups and delegate authority to local or national governments, leading to the associated risk of state failure. They can facilitate the emergence of violent groups to justify acts of terrorism or worsen diplomatic relations between countries.(Middle East Monitor, 2019)

Currently, the water resources of each country are not equal. Therefore, to be able to maintain clean water in a sustainable way, countries must share with each other about water resources. In order to ensure the reasonable and effective governance and sharing of the transnational water system, countries around the world have signed many conventions and legal assessments to ensure fairness. such as: 1997 New York Convention, 1995 Mekong Agreement, 1992 Helsinki Convention...(Vụ Luật pháp và Điều ước quốc tế - Bộ Ngoại giao, 2015) The Agreement on Sustainable Development Cooperation in the Mekong River Basin signed in 1995 between Cambodia, Laos, Vietnam and Thailand is considered a progressive river basin cooperation agreement in the world. The Agreement stipulates specific provisions on exploitation and use of water resources, environmental protection, implementation organization and responsibilities and interests of the parties towards the goal of sustainable development of the basin. The 1997 Law on the Non-Navigational Uses of Water Resources for NonNavigational Purposes was the first global convention governing the relations between States in the equitable and equitable use of transnational watercourses. Between upstream and downstream, the performance of obligations should not cause significant harm to the States concerned in accordance with international principles and standards.(Nguyễn Chiến Thắng, 2021) The principle of "water users must pay" has been included in the Law of 2012 under the provisions on "Money for granting mining rights". Water has been treated as a commodity product; activities to protect and develop water resources are carried out in the direction of socialization; adopt policies to encourage organizations and individuals to participate in the development of water services and to use water economically and efficiently.(Cục Quản lí tài nguyên nước - Bộ Tài nguyên và Môi trường, 2014)

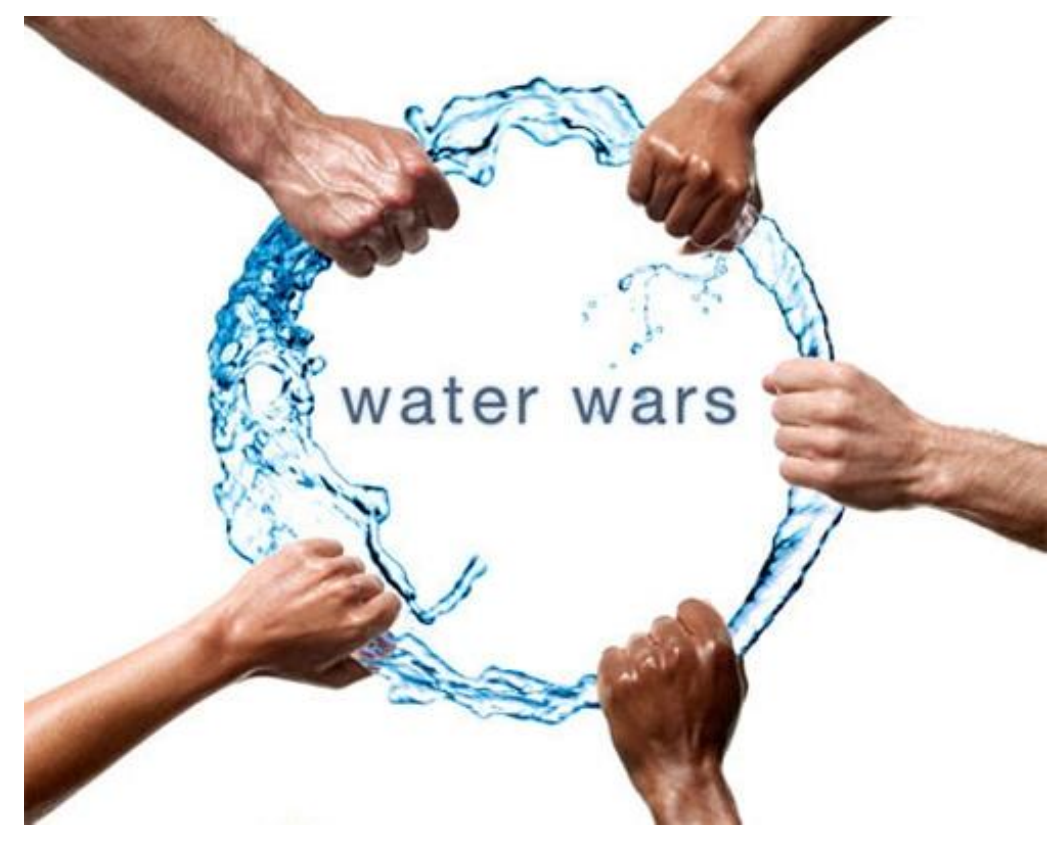

Figure 3. Protecting water is a way to protect our own lives. (Source: ctn kh.com.vn)

Recognizing the important position of freshwater resources, a number of countries have also joined hands to develop policies and studies to maintain and protect this resource. For example, using advanced 
technology to save water as well as create fresh water from other types of water: drip irrigation, sea water desalination pioneered by Israel, wastewater treatment into drinking water is typical. Singapore... Vietnam also actively joins hands with countries around the world in efforts to protect water resources such as tightening legal penalties, educating people's sense of water protection and saving,...(Healthy Water, 2020) According to Article 26 of the Vietnam Water Resources Code 2012 on prevention and control of water pollution and depletion: "The exploitation and use of water resources must comply with the master plan on water resources approved by the competent authority. Browser; if it degrades the function of the water source, causes subsidence or subsidence, pollutes or salinizes the water source, it must be responsible for remedying the consequences; if it causes damage, it must pay compensation according to the provisions of law. ”.(Theo Bộ Luật Tài Nguyên Nước Quốc Hội Ban Hành Năm 2012, Căn Cứ Hiến Pháp Nước Cộng Hoà Xã Hội Chủ Nghĩa Việt Nam Năm 1992 Đã Được Sửa Đổi, Bổ Sung Một Số Điều Theo Nghị Quyết Số 51/2001/QH10, 2012) Besides establishing and perfecting sanctions for acts harmful to the water environment, the Vietnamese government also has a number of plans to improve the clean water treatment system. More specifically, to solve the problem of depletion of water resources in the colonial river basins, our state has introduced a number of measures to plan and complete hydropower, irrigation, reservoir systems, ... at the same time combined with the development and implementation of appropriate investment policies to join hands in protecting clean water sources, using resources more efficiently and economically.

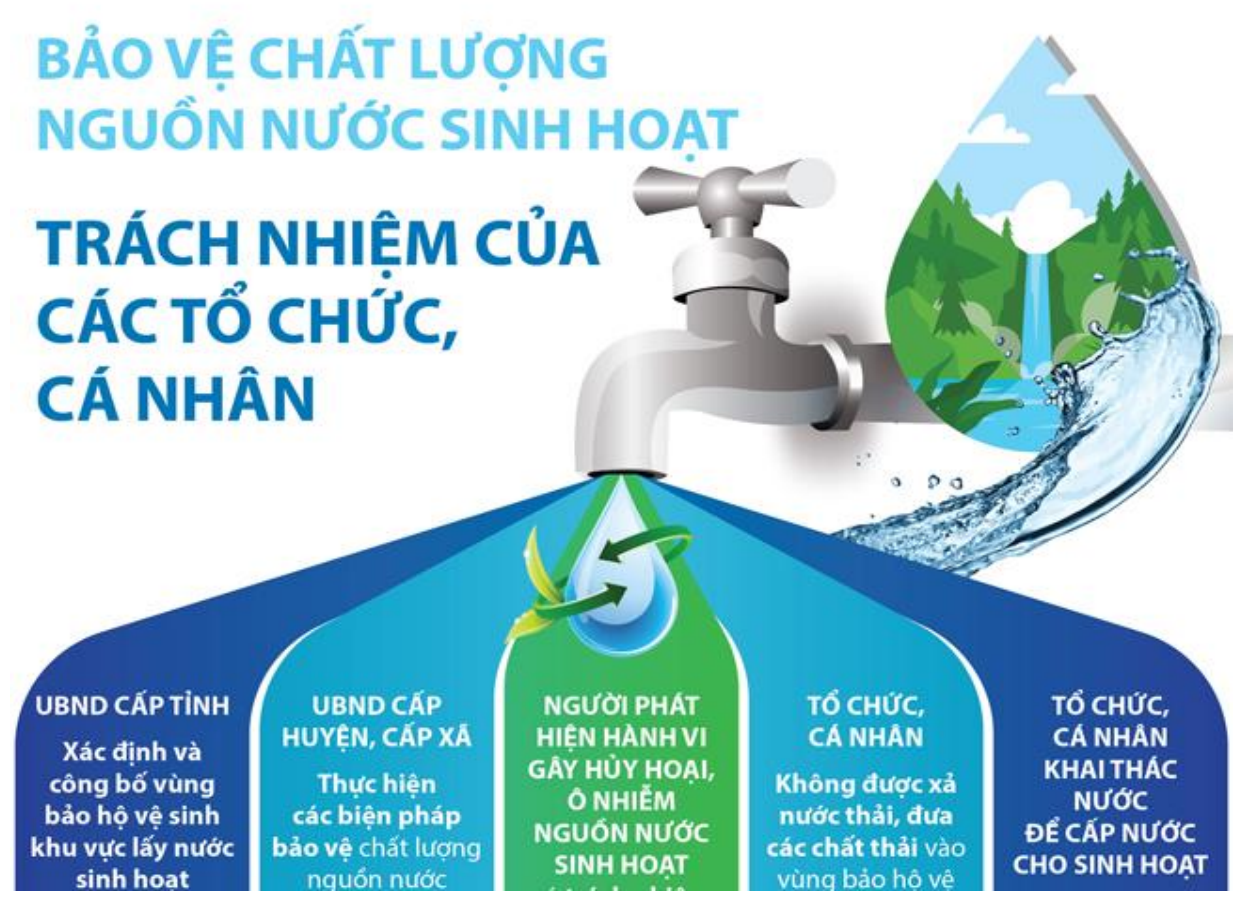

Figure 4. Who will be responsible for protecting the quality of domestic water sources? (Source: baotintuc.vn)

Protecting clean water sources is not the work of an individual, organization or group, but of the whole society and community. Therefore, in order to solve the above environmental problems, it is necessary to have an overall research plan and a rational plan for the use of water resources (Vuong, Q. H., 2022; Q.-H. Vuong, 2021; Q. H. Vuong, 2021). At the same time, the Government needs to promptly issue preferential policies to encourage the community to use water sparingly to minimize negative impacts on natural clean water sources.

\section{REFERENCES}

Chi, L. (2021, January 8). Giải pháp nào cho xủ lí rác thải tại Việt Nam. Báo Lao Động.

https://laodong.vn/moi-truong/giai-phap-nao-cho-xu-ly-rac-thai-tai-viet-nam-977017.ldo

Cục Quản lí tài nguyên nước - Bộ Tài nguyên và Môi trường. (2014, January 7). Quản lí tổng hợp tài nguyên nuớc và chính sách bảo vệ nguồn nước quốc gia. Hội Thảo "Quốc Hội Với Việc Đị̣nh Hình Cơ Chế Mới về Quản Trị Nước.” http://www.dwrm.gov.vn/uploads/download/files/11-quan-ly-tong-hop-tai-nguyen- 
nuoc-va-chinh-sach-bao-ve-nguon-nuoc-quoc-gia_chau-tran-vinh_vn.doc

Eco248. (2021, January 8). Thục trang ô nhiếm môi trường nước ở Việt Nam hiện nay. Eco248.

https://eco248.com/thuc-trang-o-nhiem-moi-truong-nuoc-o-viet-nam-hien-nay

Healthy Water. (2020, January 8). Các giải pháp bảo vệ môi trương nước tại Việt Nam. Healthy Water.

Joel Podgorski, M. B. (2020). Global threat of arsenic in groundwater. Science, 368, 845.

https://www.science.org/doi/full/10.1126/science.aba1510

Middle East Monitor. (2019, January 7). Water scarity and conflict: Not such a straightforward link. ECDPM. https://www2.hcmuaf.edu.vn/data/quoctuan/Tai nguyen nuoc va hien trang su dung nuoc.pdf

Nguyễn Chiến Thắng, H. G. M. (2021, January 8). Bài 3: Bảo vệ nguồn nước là bảo vệ sự sống. Báo Quân Đội Nhân Dân. https://www.qdnd.vn/xa-hoi/cac-van-de/bai-3-bao-ve-nguon-nuoc-la-bao-ve-su-song654725

Nhóm thực hiện Trường Đại học Nông Lâm Thành phố Hồ Chí Minh. (2013, January 8). Tài nguyên nước và hiện trạng sử dụng nước. https://www2.hcmuaf.edu.vn/data/quoctuan/Tai nguyen nuoc va hien trang su dung nuoc.pdf

Nước, C. quản lí tài nguyên. (2021, January 8). Nước ngọt - nguồn tài nguyên đang cạn kiệt. Cục Quản Lí Tài Nguyên Nước. http://dwrm.gov.vn/index.php/vi/news/Tai-nguyen-nuoc/Nuoc-ngot-nguon-tai-nguyendang-can-kiet-189/

Phụng, T. H. K. (2021, January 8). Thưc trạng ô nhiễm môi truờng nước vè trách nhiệm bảo vệ nguồn nước sạch. Cổng Thông Tin Điện Tử Quận Tân Bình.

https://tanbinh.hochiminhcity.gov.vn/web/neoportal/danh-muc-tin-tuc-su-kien/-

/asset_publisher/VN5j2Vj9DHkT/content/thuc-trang-o-nhiem-moi-truong-nuoc-va-trach-nhiem-bao-venguon-nuoc-sach?inheritRedirect=false

Theo Bộ Luật Tài nguyên nước Quốc Hội ban hành năm 2012, căn cứ Hiến pháp nước Cộng hoà xã hội chủ nghĩa Việt Nam năm 1992 đã được sửa đổi, bổ sung một số điều theo Nghị quyết số 51/2001/QH10, (2012).

Rekacewicz, P. (2008, January 8). Freshwater Availability. National Geographic Social. https://www.nationalgeographic.org/photo/waterstress-2008-unep/

Sơn, N. (2020, January 8). FAO kêu gọi nhanh chóng giải quyết tình trạng thiếu nước trên toàn cầu. Kiếm Toán Nhà Nước. http://baokiemtoannhanuoc.vn/quoc-te/fao-keu-goi-nhanh-chong-giai-quyet-tinh-trangthieu-nuoc-tren-toan-cau-146147

Thiennhien.net. (2021, January 8). Khan hiếm nước - thách thức toàn cầu. Trang Tin Điện Tử Của Ủy Ban Dân Tộc.

http://web.cema.gov.vn/modules.php?name=News\&op=Print\&mid=3710\&fbclid=IwAR3F0tujXLPNgX FkBmymJ3Qy_Uc6TVQOc3cj3cga8BhHrIOrnPiBs6xrfCo

Thoan, V. (2021, January 8). Thực trạng ô nhiếm môi trương nước hiện nay. Môi Trường CCEP. https://ccep.com.vn/thuc-trang-o-nhiem-moi-truong-nuoc/

Vụ Luật pháp và Điều ước quốc tế - Bộ Ngoại giao. (2015, January 8). Tổng quan hệ thống điều uớc quốc tế liên quan đến quản trị nguồn nước và nhũng vấn đề đặt ra trong quá trình hội nhập quốc tế. http://www.vncold.vn/Modules/CMS/Upload/10/TuLieu/150803/ThamLuanBoNgoaiGiao.pdf

Vuong, Q. H., et al. (2022). Covid-19 vaccines production and societal immunization under the serendipity-mindsponge-3D knowledge management theory and conceptual framework. Humanities and Social Sciences Communications, 9, 22. Retrieved from: https://www.nature.com/articles/s41599-022-01034-6

Vuong, Q.-H. (2021). Western monopoly of climate science is creating an eco-deficit culture. Economy, Land \& Climate Insight, 11, 1-9. https://elc-insight.org/western-monopoly-of-climat

Vuong, Q. H. (2021). The semiconducting principle of monetary and environmental values exchange. Economics and Business Letters, 10(3), 284-290. https://doi.org/10.17811/ebl.10.3.2021.284-290 